\title{
Consumer's Trust in the Brand: Can it Be Built through Brand Reputation, Brand Competence and Brand Predictability
}

\author{
Hasan Afzal (Corresponding Address) \\ Independent Researcher, Hong Kong \\ House No 1903 Un Shing House, Un Chau Estate \\ Cheung Sha Wan, Kowloon, Hong Kong
}

Tel: 852-9301-911Ｅ-mail: hasanmphil@gmail.com

Muhammad Aslam Khan

Faculty of Business Administration

Preston University, Islamabad, Pakistan

Tel: 92-300-555-5084 E-mail: aslamnuml@yahoo.com

\author{
Kashif ur Rehman \\ Department of Management Sciences \\ Iqra University Islamabad, Pakistan \\ Tel: 92-321-537-4723 E-mail: dr.kashifurrehman@gmail.com \\ Imran Ali \\ Management Science Department \\ COMSATS Institute of Information Technology, Lahore, Pakistan \\ Tel: 92-321-504-1925 E-mail: imranali@ciitlahore.edu.pk \\ Sobia Wajahat \\ Department of Management Sciences \\ HITEC University Taxila, Pakistan \\ Tel: 92-321-501-8989 E-mail: sobia_hitec@yahoo.com
}

\begin{abstract}
The study evaluated the relationship of Brand Reputation, Brand Competence and Brand Predictability in the context of Consumer's Trust in the Brand. The data was collected through a self reported questionnaire administered to the respondents. Results were evaluated through Correlation and Regression Analysis, all models are significant at $5 \%$ level. The results show that consumer's trust in the brand increased between 30 percent and 60 percent due to Brand Characteristic. Results indicate that Brand Reputation, Brand Predictability and Brand Competency are the factors which affect consumer's trust on brand. After the analysis it is proved that brand reputation, predictability and competency has positive impact on trust. Consumer trust in brand is build up when; consumer uses that brand and gathers data about brand reputation, its predictability and competencies. When brand reputation is good, it meets the predictability of customer and it has competency to satisfy the customer's needs, it helps to develops trust of customer on brand. By using effective advertising techniques, brands must build their image which in turn would build customer trust and credibility. Brands must try to build their competencies so that customer needs can be satisfied
\end{abstract}

Keywords: Brand Reputation, Brand Competence, Brand Predictability, Consumer's Trust in the Brand

\section{Introduction}

Brand is defined by different researchers and authors in different ways. Aaker \& Keller (1990) defined Brand as a name, logo, trademark, and symbol. A seller is granted exclusive right to use brand. Basically it is different from patents and copyright (other assets), which have expiry date (Kotler and Armstrong, 2004). Owners sell their brand in market at 
their own will and cost on competitive basis. According to Einwiller (2001) a brand creates difference with other generic products.

Brand is considered as a reflection of the spirit and soul of an organization. This proclamation proposes that brand is not representation of a company's product; it is name, logo, trademark, and symbol of firm that distinguishes it and that is where the core of brand loyalty takes its position. Brand show loyalty of end users. After continuous usage of brand, consumers feel it as part of them (Aaker, 1991).

Trust means confidence on exchange partner's reliability and integrity (Morgan and Hunt 1994). Trust shows consumer commitment and satisfaction with particular brand. An organization uses trust in brand as a risk-reduction mechanism (Doney and Cannon 1997). Trust can also be considered as goodwill and willingness that enables the consumer to take risk. Goodwill is developed on the bases of past experiences. Trust is an expectation, which may cause a positive outcome, despite the possibility that it may cause a negative outcome (Worchel, 1979). So expectation of groups or teams in an event is called trust (Deutsch 1958). Trust is not a mere predictability but confidence in the face of risk (Lewis and Weigert (1985). Trust is a psychosomatic state comprising the intention to recognize susceptibility based upon constructive prospect of the intentions or behavior of another person (Rousseau et. al., 1998). For making a strong relationship between buyer and seller, creation of trust is a very important factor in business environment. Trust is a feeling about satisfaction because of its ability to moderate risk in the buying process (Anderson and Narus, 1990; Dawyer, Schurr and Oh, 1987).

According to O'Shaughnessy (1992) faithfulness is everlasting wish, a readiness to do something with no computation of instant expenses and profit. Hence, faithfulness to a brand engages trust in it. In business marketing, the idea of faith is sound to develop (e.g. Ganesan, 1994; Doney and Cannon, 1997) and a great deal of endeavor has been used up in discovering methods to construct and keep it. In that background, trust is constructed on the basis of person-to-person dealings. Trust in a product is different from interpersonal trust because a brand is a sign. Unlike a salesperson, this sign is not capable to react to the customer. To create loyalty in today's marketplace, marketers have to hold what is becoming subsequent nature to business marketers (Donath, 1999) and focus on structuring and sustaining trust in the customer-brand relationship. Unfortunately, the idea of trust in consumer marketing is largely unexplored.

This study is conducted to evaluate the constructive effects of brand characteristics on consumer's trust in the brand. This study is focused on the cities of Pakistan. As research has been done to find out what consumers think while buying a certain brand and what other factors influence the opinion about the same brand. This study helps in checking the trust of consumers in brand.

In this paper, factors related to brand reputation, brand competence and brand predictability are explored. Effects of these independent variables are examined on trust in brand. Brand attributes are main aspect which can improve consumer satisfaction level. Consumer wants a brand at a lower price and with attributes which can satisfy his/her needs. When consumer uses a brand and his/her need is not satisfied, then he/she may not use same brand again. Consumers also share their brand usage experience with others. This kind of data sharing can also create new consumers who may also try to use that brand. Brand characteristics are main aspects of brand which can satisfy needs of customers. Business firms must try to build their brand image through customer's needs satisfaction. Customer's needs satisfying ability of brand is also capable of building consumer trust in brand. When brands fail to satisfy customer needs they may switch to other brands.

\section{Consumer's Trust in the Brand}

Trust means expectation from others on specific task, and expectations vary between high and low rating scale. Variation of expectations is called risk. Trust is dependency on other parties at the level of risk with their own willingness. Trust is built up on the bases of past experiences. Trust is based on ending results. A positive ending result enhances trust and negative results on the other hand will cause the trust to drop (Deutsch, 1958; Worchel, 1979). Trust plays a vital role for developing and maintaining brand loyalty in both situations, i.e. consumer-to-business and business-to-business buying situation. To maintain a market share and price elasticity, trust influence toward changing behavioral and attitudinal loyalty (Chaudhuri, and Holbrook, 2001). Trust is a belief which is focused on specific appropriate boundaries and limitations. Lewis and Weigert (1985) say that trust is not mere certainty but assurance in the expression of risk. Many other researchers have followed this idea (Deustch, 1960; Schlenker et al., 1973; Boon and Holmes, 1991). Boon and Holmes (1991) defined trust as a condition linking certain optimistic opportunity about another's intention with respect to oneself in risky state of affairs. Consumer's trust in brand is a variable that generates customers' commitment, particularly high involvement situation, in which its effect is strong in assessment as a whole contentment (Moorman, Zaltman, and Deshpande, 1992; Morgan, and Hunt, 1994; Delgado and Munuera 2001).

In business marketing trust plays important role. Apart from change of aggressive modifications, Industrial-marketing organizations adopt new methods to be competitive. Another method is by maintaining good links with the consumers. It is an easy and less expensive tactic because in the business market, small numbers of consumers buy large number of 
products. Different forms of trade in the market are distinguished by huge area of trust (Dwyer, Schurr and Oh, 1987; Morgan and Hunt, 1994). Owing to this, emphasizing is laid on the strategic outcomes of the relationship (Ganesan, 1994); thus enhancing competitiveness and reducing transaction expenses (Noordewier, John and Nevin, 1990).

The business and marketing literature reveals different ways to build trust. Trust is emphasized either as a part of linkage quality (Dwyer and Oh, 1987; Crosby, Evans, and Cowles, 1990; Anderson, Lodish, and Weitz, 1987), or as a determinant of relationship quality (Anderson and Narus, 1984, 1990; Parasuraman, Ziethaml, and Berry, 1985; Anderson and Weitz, (1990). Doney and Cannon (1997) presented apparent trustworthiness and kindness of the object as areas of trust. Apparent trustworthiness centers on the objective trustworthiness of the trade partner, the anticipation that the partner's word or paper declaration can be trusted. Kindness is the level to which one partner is actually interested in the other's benefit and forced to seek cooperative benefit. Evolution of trust is through a procedure of computation, the expenses and benefits of both sides leaving or being in the relationship.

Previously, trades in customer-product business faced larger issues as large amount of customers were faithful to transaction only (Donath, 1999). To triumph customer faithfulness and for imitating achievement of business, marketers started to hold the thought of making links with consumers to get their faith (Bennet, 1996). Idea of faith in the marketing text normally lacks. In the buyer market, there are number of unidentified buyers, which make it difficult to link with customers. The trade name becomes an alternate for personal link amongst the seller and buyer.

\section{Brand Characteristics}

Brand constituent, brand reputation and brand competence assist for developing consumer trust in brand. Before purchasing a brand, consumers judge brand through these characteristics (Lau and Lee, 1999). The brand's properties have an important function in shaping consumer trust. Many buyers see other buyers to evaluate brand capabilities in market and also evaluate the benefits which they can get from those brands. Buyers develop trust in brand on the foundation of the market worth of brands (Zucker, 1986), certainty (Remple Holmes, and Zanna, 1985) and capability (Andaleep and Anwar, 1996).

\subsection{Brand Reputation}

"Reputation, reputation, reputation, O! I have lost my reputation. I have lost the immortal part of my self and what remains is bestial" (Shakespeare's Quotation)

High demand of brand indicates high reputation in the mind of consumers. A well thought-of brand is a powerful asset. Advertising channels, public relations elements and customers should be encouraged to spread positive word-of-mouth. As a Chinese quotation goes, "Good news does not become known, but bad news spreads far and wide". Good reputation could lead to positive expectations and bad reputation could lead to negative image of the brand (Creed and Miles, 1996). For complete understanding of brand trust, a brand must be examined, assessed and checked as to how much it is related with brand loyalty (Lau and Lee, 1999). Consumer holds brands as a part of product with value addition and that brand creates difference from other products. Basically consumers rely on brand with a level of risk (Moorman, Zaltman, and Deshpande, 1992). Reputation means trustworthiness, integrity, and honesty. It can be seen from past experience of third party's trustworthiness, integrity, and honesty. Brand reputation can be judged from consumer opinion, comments, estimation and beliefs, if people are suggesting the usage of a brand then it is considered as a sign of good reputation. A brand's reputation refers to the attitude of consumers that the brand is good and reliable. Brand reputation can be developed through advertising and public relations, and it enhances its quality.

A brand's standing refers to the concept of other buyers about brand worth in the market. Reputation and standing of brand can be created by effective marketing and making links with customers. Creed and Miles (1996) established that brand standing in market creates optimistic outcomes, which result in the expansion of reciprocity between both entities. If a buyer assumes that other buyers also have same opinion about brand as worthy of praise, he/she also trusts that brand and make buying decision. But if that product or brand does not meet customer needs then he/she may not buy it. On the other hand, if brand name does not have a good value, customer is likely to be more doubtful. As a consequence of sensitive alertness, they might not trust the brand. As a result, the following hypothesis is developed:

$\mathrm{H}_{1}$ Brand Reputation is positively related to the Consumer's Trust in the Brand

\subsection{Brand Competence}

A competent brand is one that has the ability to crack a customer's problem and to meet the need (Butler and Cantrell, 1984; Butler, 1991). Every organization wants to establish their competence in a few key areas, and deal with their brand within these realms. It is a duty of every marketer to find out exact demands of their customers which are related with their product. Organization should not create doubt in the mind of consumer about brand competence. Consumers must be persuaded regarding the brand competence. Marketers should make well-judged use of key opinion leaders, who are viewed as authorities in specific areas, and to present them a persona of the brand. Highly qualified engineers for technical equipment and well-known physicians for pharmaceutical products are examples of key opinion leaders. 
Competent brand includes crucial elements for solving consumers' problem. Utilization of brand is only one way to find out brand competency (Lau, and Lee, 1999; Christou, 2004). Consumers can find out a brand's competency through direct usage or word-of mouth.

Good brands are that which are able to satisfy the needs of a customer and its attributes must be compatible with customer's needs. Brand ability is the properties of brand which are perceived by customer as value. Butler and Cantrell (1984), Butler (1991), Deutsch (1960), Cook and Wall (1980), and Sitkin and Roth (1998) measured it as a property to satisfy the needs of customer.

A buyer can only know about brand attributes after using it and after listening from others. When customer perceives that brand can satisfy his needs, only then he /she can be able to involved in buying decision. The literature suggests creating the following hypothesis.

$\mathrm{H} 2$ Brand Competency is positively related to the Consumer's Trust in the Brand.

\subsection{Brand Predictability}

Predictability is ability of one buyer which is perceived by the other buyer (Doney and Cannon, 1997). It is a brand which allows customer to perceive brand characteristics, with trust that brand will satisfy his/her needs. Predictability is also dependent on product attributes and brand worth. When a consumer predicts about a brand while being used by other consumer, then this shows that he predicts about that product.

Shapiro, Sheppard, and Cheraskin, (1992) recognized three types of trust in service: deterrence-based faith, knowledge-based trust, and identification-based trust. Of these, knowledge-based trust, stranded in behavioral certainty survives while one party has sufficient knowledge concerning another to recognize and forecast its likely performance that it will perform trustworthily (Linskold, 1978; Rotter, 1971). Kelly and Stahelski (1970) argued that certainty improves faith, even if the additional party is surprisingly not trustworthy, because the behavior in which faith is dishonored can be forecasted. A brand's obviousness enhances assurance because the customer knows that nothing unforeseen may occur when it is used. As such, product predictability enhances trust in a brand because certainty builds optimistic outlook (Kasperson, Golding, and Tuler, 1992). Based on this relationship the following hypotheses is derived

H3 Brand predictability is positively related to the Consumer's trust in the brand.

\section{Method}

\subsection{Sample}

Target population was consumers of Rawalpindi and Islamabad, Pakistan, who were purchasing any consumer goods. Six hundred and forty questionnaires were administered to different centers, shopping malls, markets and markaz. Of those, a total of 328 questionnaires were received back. All consumers answered with special reference to non-durable consumer brand items. It became point of interest for the consumers as the questionnaire asked about favorite brand and product. A number of studies have been conducted on brand reputation, brand competence, brand predictability and consumer's trust in brand with the Lau and Lee (1999), Remple et al., (1985); Lazelere and Huson's(1980) instruments; but their reliability under the Pakistani environment is to be judged.

\subsection{Instrument and Measures}

Brand Reputation's scale by Lau and Lee (1999) with little modification is used to for measuring the response. It consists of six items that measures the respondent's point of view regarding the brand goodness, reliability and what other people have said about the brand goodness and reliability. Five point likert scale was used as 1 for strongly disagree and 5 for strongly agree. Three items were used as reverse coding. Lau and Lee (1999) scale proved its reliability of 0.87 whereas this research shows 0.78 reliability factors.

To measure Brand Competence the scale by Lau and Lee (1999) with little modification was adopted. To operationalise the brand competence, it is apt to measure brand perception regarding its competence. Analysis of brand competence in relation to other brands competency was a need to be done for comparison. This measurement process would be a genuine instrument to ascertain its success. Five point likert scale was used as 1 for strongly disagree and 5 for strongly agree. One item was used as reverse coding. Lau and Lee (1999) scale for brand competence proved its reliability of 0.94 whereas this research shows reliability of 0.82 .

Three constructs were adapted form Remple, Holmes, and Zanna, (1985), and three from Lau and Lee (1999) to measure brand predictability. These six items show brand consistency in quality and performance. Five point likert scale was used as 1 for strongly disagree and 5 for strongly agree. Two items were reverse coded. The brand predictability scale proved its reliability of 0.91 whereas this research shows reliability of 0.86 .

The operationalisation of Consumer's Trust in the Brand includes searching out feedback from the consumer. The established trust factor is likely to yield its outcome as it is perceived. For measuring trust in brand, two items are 
adapted from Lazelere and Huson's (1980), while three items of trust were adapted from the Remple, Holmes, and Zanna, (1985). Five point likert scale was used as 1 for strongly disagree and 5 for strongly agree. Two items were used as reverse coding. The research shows reliability of 0.81 for this scale.

\subsection{Procedure}

Questionnaires were distributed randomly to consumer in capital city of Islamabad and Rawalpindi, Pakistan. Questionnaire contained two parts, first part related to demographic profiles and second part consisted of brand reputation, brand competence, brand predictability and consumer trust in the brand. To reduce the bias in response, several items were in reverse coding. Pakistan's official language is English, therefore, the questionnaire was not translated in native language but where necessary, oral translation was made in local easy languages.

\section{Results and Discussion}

The response rate of 50 percent was noticed as 328 questionnaires completed in all respect were received. There was no statistical difference between gender, age and qualification. The data recording the age, gender and qualification of the respondents shows that 73 percent of respondent's age was 20 to 30, only 20 percent were female and 60 percent respondent's education was Intermediate. People highlighted 98 brands during the survey.

Table No-1 shows means standard deviations and cronbach's of the data. The results reveal that Brand Reputation has the largest mean 3.3943 while Brand Predictability has the lowest mean of 3.2403. Standard deviation ranged from 0.56681 to 0.7539 . The international consistency method was used to examine the reliability of each variable.

Table No-2 reveals the Pearson correlation of Brand Reputation, Brand Predictability, Brand Competence and Consumer's Trust in the Brand and their significance. Evidence shows that each variable is correlated to the other and their relation is significant at $95 \%$ confidence level $(\mathrm{p}<0.05)$. Individual basis correlation coefficient of Brand Reputation with relations to Brand Predictability, Brand Competence and Consumer's Trust in Brand are positively associated at $.305, .413$ and .238 respectively and their relation is significant at 95 percent. Coefficient of Correlation of Brand Predictability with relations to Brand Competence, Consumer's Trust in the Brand is .288 and .287 respectively and their relation is significant at 95 percent. Coefficient of Correlation of Brand Competence with Consumer's Trust in the Brand is positively at .524 and their relation is significant at 95 percent. This study shows that all relationships between variables are positive.

Table No-3 shows the regression analysis of Brand Reputation and Consumer's Trust in Brand. R Squares is 0.57 and F-Value is 19.549.The 0verall model is significant at 95\%. R Square shows the strong relationship between each variable and beta coefficient is at .296 which shows Consumer' Trust in the Brand is increased 30 percent due to Brand Reputation: t-value is 4.4421 which show relevant importance of brand reputation for consumer's trust in the brand. Overall model shows that consumer trust has significant impact on brand and this indicates that trust can be achieved if brand fulfills needs of customers.

Table No-4 shows the regression analysis of Brand Competence and Consumer's Trust in Brand. R Squares is 0.275 and F-Value is 123.549. Overall model is significant at 95\%. R Square shows the strong relationship between each variable and beta coefficient is .60 which shows consumer' Trust in brand increases 60 percent due to Brand Competence and t-value of 11.115 shows relevant importance of brand competence for consumer's trust in the brand. Brand competence is also important feature which develop consumer trust in brand. Brand must have certain characteristics which can satisfy the needs of consumer. Brand must have characteristics which are same that are required to meet consumer needs. Brands which don't have brand characteristics would not be able to meet consumer need and that brand may not succeed in the marketplace.

Table No-5 shows the regression analysis of Brand Predictability and Consumer's Trust in Brand. R Squares is 0.083 and F-Value is 29.371 and overall model is significant at $95 \%$. R Square shows the positive relationship between each variable and beta coefficient is .324 which shows consumer's Trust in brand increases by 32 percent due to Brand Predictability: t-value is 4.4421 which shows relevant importance of brand reputation for consumer's trust in the brand.

Brand predictability also affects consumer trust. When consumer has predictions about any brand and after brand usage those predictions come true, that affects the trust of consumer on brand. Predictability is created when consumer listens about brand from other users and on the basis of that if consumer has same experience. Customer's trust can be developed when brand satisfy his needs.

\section{Conclusion and Recommendations}

This study provides interesting findings through correlation and regression analysis. The study predicts positive impact of Brand Reputation, Brand Competence and Brand Predictability on Consumer's Trust in the Brand. The study model is significant at $95 \%$ of confidence level $(\mathrm{p}<0.05)$. Furthermore Consumer's Trust in Brand increases between 30 percent and 60 percent due to Brand Characteristics (Brand Reputation, Brand Competence and Brand Predictability). 
Regression and correlation analysis shows that Brand Reputation has positive relationship with Consumer's Trust in the Brand and it is significant at 95 percent confidence level. R Square is .57, coefficient Beta is 30 percent and Pearson Correlation is 24 Percent. So we accept H1 (Brand Reputation is positively related to the Consumer's Trust in the Brand). Second independent variable, Brand Competence has positive impact on Consumer's Trust in the Brand and it is significant at 95 percent confidence level. $\mathrm{R}$ Square is 0.28 , coefficient Beta is 60 percent and Pearson Correlation is 52 Percent. So we accept H2 (Brand Competent is positively related to the Consumer's Trust in the Brand). Second independent variable, Brand Predictability, has positive impact on Consumer's Trust in the Brand and it is significant at 95 percent confidence level. R Square is 0.083 , coefficient Beta is 32 percent and Pearson Correlation is 29 Percent. So we accept H3 (Brand Predictable is positively related to the Consumer's Trust in the Brand). The results of this research study are almost consistent with the study conducted by Lau and Lee (1999) that there is relationship of Brand Characteristic (Brand Reputation, Brand Competence and Brand Predictability) with Consumer's Trust in the Brand.

Brand Reputation, Predictability and its Competency are the factors which affect consumer trust in brand. The analysis of the study proves that brand reputation, predictability and its competency has positive impact on trust which is developed when consumer uses that brand and gathers data about brand reputation, its predictability and competencies. When brand reputation is good, it meets the predictability of customer and it has competency to satisfy the needs of customer, and thus it develops trust of customer in brand.

\subsection{Further Recommendations}

Brands must build customer trust to improve their image in market. Brands must hold good quality to satisfy customer's need. By using effective advertising techniques, brands must build their image which in turn would build customer trust and credibility. Brands must try to build their competencies so that customer needs can be satisfied

\section{References}

Aaker, D. A. (1991). "Managing Brand Equity: Capitalizing on the Value of a Brand Nam"e. NY: The Free Press.

Andaleep, S. S. and Anwar, S. F. (1996). "Factors Influencing Customer Trust in Salespersons in a Developing Country," Journal of International Marketing, Vol. 4, No. 4, pp. 35-52.

Anderson, E. and Weitz, B. (1990). "Determinants of Continuity in Conventional Industrial Channel Dyads," Marketing Science, Vol. 8, pp. 310-323.

Anderson, E., Lodish, L. and Weitz, B. (1987). "Resource Allocation Behavior in Conventional Channels," Journal of Marketing Research, Vol. 24, pp. 254-262.

Anderson, J. C. and Narus, A. (1990), "A model of distributor firm and manufacturing firm working partnership". Journal of Marketing 54, pp. 42-58.

Anderson, J. C. and Narus, A. (1984). “A Model of the Distributors' Perspective of Distributor-Manufacturer Working Relationships," Journal of Marketing, Vol. 48, pp. 62-74.

Bennet, R. (1996). "Relationship Formation and Governance in Consumer Markets: Transactional Analysis versus the Behaviorist Approach," Journal of Marketing Management, Vol. 12, pp. 417-436.

Boon, S. D. and Holmes, J. G. (1991). "The Dynamics of Interpersonal Trust: Resolving Uncertainty in the Face of Risk.” In R. A. Hinde and J. Groebel (Eds.), Cooperation and Prosocial Behavior, 190-211, Cambridge, UK: Cambridge University Press.

Butler, J. K. (1991). "Toward Understanding and Measuring Conditions of Trust: Evolution of a Conditions of Trust Inventory," Journal of Management, Vol. 17, pp. 643-663.

Butler, J. K. and Cantrell, S. R. (1984). “A Behavior Decision Theory Approach to Modeling Dyadic Trust in Superiors and Subordinates," Psychological Reports, Vol. 55, pp. 19-28.

Chaudhuri, A. and Holbrook, M. B. (2001). "The chain of effects from brand trust and brand affect to brand performance: The role of brand loyalty". Journal of Marketing 65, pp. 81-93.

Christou, E. (2004). "Guest loyalty likelihood in relation to Hotels' corporate image and reputation: A study of three countries in Europe". Journal of Hospitality and Leisure Marketing, 10, pp. 88-99.

Cook, J. and Wall, T. (1980). "NewWork Attitude Measures of Trust, Organisational Commitment, and Personal Need Nonfulfillment," Journal of Occupational Psychology, Vol. 53, pp. 39-52.

Creed, W. E. D. and Miles, R. E. (1996), “Trust in Organizations: A Conceptual Framework Linking Organizational Forms, Managerial Philosophies, and the Opportunity Cost of Controls.” In R.M. Kramer and T. R. Tyler (eds.), Trust in Organizations: Frontiers of Theory and Research, Sage Publications, Inc.

Crosby, L. A., Evans, K. R. and Cowles, D. (1990). "Relationship Quality in Services Selling: An Interpersonal Influence Perspective," Journal of Marketing, Vol. 54, pp. 68-81. 
Dawyer, F. R., Schurr, P. H. and Oh, S. (1987). “Developing buyer-seller relationships”. Journal of Marketing 51, pp. 11-27.

Delgado-Ballester, E. and Munuera- Aleman, J. L. (2001). "Brand trust in the context of consumer loyalty". European Journal of Marketing 35, pp.1238- 1258.

Deutsch, M. (1958), “Trust and suspicion”. Journal of Conflict Resolution. 2, pp. 265-279.

Donath, B. (1999). “Consumer marketing trends”. Marketing News. 28, pp. 14-27.

Doney, P. M. and Cannon, J. P. (1997). “An Examination of the Nature of Trust in Buyer-Seller Relationships,”Journal of Marketing, April, pp. 35-51.

Dwyer, F. R., Schurr, P. H. and Oh, S. (1987). “Developing Buyer-Seller Relationships,” Journal of Marketing, Vol. 51, pp. 11-27.

Dwyer, F.R. and Oh, S. (1987). "Output Sector Munificence Effects on the Internal Political Economy of Marketing Channels," Journal of Marketing Research, Vol. 24, pp. 347-358.

Einwiller, S. (2001). "The significance of reputation and brand for creating trust in the different stages of a relationship between an online vendor and its customers. Eighth Research Symposium on Emerging Electronic Markets.

Ganesan, S. (1994). "Determinants of Long-Term Orientation in Buyer-Seller Relationships," Journal of Marketing, Vol. 58, pp. 1-19.

Kasperson, R. E., Golding, D. and Tuler, S. (1992). "Social Distrust as a Factor in Siting Hazardous Facilities and Communicating Risks," Journal of Social Issues, Vol. 48, No. 4, pp. 161-187.

Kelly, H. H. and Stahelski, A. J. (1970). "Social Interaction Basis of Cooperators' and Competitors' Beliefs about Others," Journal of Personality and Social Psychology, Vol. 16, pp. 66-91.

Kotler, P. and Armstrong, G. (2004). "Principles of Marketing”. 11 ${ }^{\text {th }}$ edn. Prentice Hall/Pearson Education.

Larzelere, R. E. and Huston, T. L. (1980). "The Dyadic Trust Scale: Toward Understanding Interpersonal Trust in Close Relationships," Journal of Marriage and the Family, August, pp. 595-604.

Lau, G. T. and Lee, S. H. (1999). "Consumers' trust in a brand and the link to brand loyalty". Journal of Market Focused Management. 4, pp. 341-370.

Lewis, J. D. and Weigert, A. (1985). “Trust as a Social Reality,” Social Forces, Vol. 63, No. 4, pp. 967-985.

Linskold, S. (1978). "Trust Development, the GRIT Proposal and the Effects of Conciliatory Acts on Conflict and Cooperation," Psychological Bulletin, Vol. 85, No. 4, pp. 772-793.

Moorman, C., Zaltman, G. and Deshpande, R. (1992). "Relationships between providers and users of market research: The dynamics of trust within and between organizations". Journal of Marketing Research. 29, pp. 314-328.

Morgan, R. M. and Hunt, S. D. (1994). "The commitment-trust theory of relationship marketing”. Journal of Marketing. 58, pp. 20-38.

Noordewier, T. G., John, G. and Nevin, J. R. (1990). "Performance Outcomes of Purchasing Arrangements in Industrial Buyer-Vendor Relationships.” Journal of Marketing, 54(4), pp. 80-93.

O’ Shaugnessy, J. (2000). “Explaining Buyer Behavior”. Oxford University Press.

Parasuramam, A., Ziethaml, V. A. and Berry, L. L. (1985). "A Conceptual Model of Service Quality and its Implications for Future Research," Journal of Marketing, Vol. 49, pp. 41-51.

Remple, J. K., Holmes, J. G. and Zanna, M. P. (1985), “Trust in Close Relationships,” Journal of Personality and Social Psychology, Vol. 49, No. 1, pp. 95-112.

Rotter, J. B. (1971). “Generalized Expectancies of Interpersonal Trust,” American Psychologist, Vol. 26, pp. 443-452.

Rousseau (1998). "Not so different after all: A cross-discipline view of trust". Academy of Management Review 23, pp. 393-404.

Schlenker, B. R., Helm, B. and Tedeschi, J. T. (1973). "The Effects of Personality and Situational Variables on Behavioral Trust," Journal of Personality and Social Psychology, Vol. 25, pp. 419-427.

Shapiro, D., Sheppard, B. H. and Cheraskin, L. (1992). "Business on a Handshake," Negotiation Journal, Vol. 8, No. 4, pp. 365-377.

Sitkins, S. and Roth, N. (1993). "Explaining the effectiveness of legalistic remedies for trust/distrust." Organizational Science. 4, pp. 367-392. 
Swan, J. E., Trawick, I. F. and Silva, D.W. (1985). "How Industrial Salespeople Gain Customer Trust," IndustrialMarketing Management, Vol. 14, pp. 203-211.

Worchel, D. (1979). "Trust and distrust” The Social Psychology in Intergroup Relations. Belmont, C A: Wadsworth.

Zucker, L. G. (1986). "Production of Trust: Institutional Sources of Economic Structure, 1840-1920.” In B. M. Staw and L. L. Cummings (Eds.), Research in Organizational Behavior, Vol. 8, pp. 53-111.

Table 1. Descriptive Analysis of Brand Characteristic and Consumer's Trust in the Brand

\begin{tabular}{lccccc}
\hline Variable & Items & N & Mean & Std. Deviation & $\begin{array}{c}\text { Cronbach's } \\
\text { Alpha }\end{array}$ \\
\hline Brand Reputation & 6 & 328 & 3.3943 & .56681 & .78 \\
Brand Competence & 6 & 328 & 3.5691 & .61591 & .82 \\
Brand Predictability & 6 & 328 & 3.2403 & .62638 & .86 \\
Consumer's Trust in Brand & 6 & 328 & 3.3701 & .70539 & .81 \\
\hline
\end{tabular}

Table 2. Pearson Correlation of Brand Characteristic and Consumer's Trust in the Brand

\begin{tabular}{|c|c|c|c|c|c|}
\hline Variables & & $\begin{array}{l}\text { Brand } \\
\text { Reputation }\end{array}$ & $\begin{array}{l}\text { Brand } \\
\text { Predictability }\end{array}$ & $\begin{array}{l}\text { Brand } \\
\text { Competence }\end{array}$ & $\begin{array}{l}\text { Consumer's } \\
\text { Trust in Brand }\end{array}$ \\
\hline \multicolumn{6}{|c|}{ Brand Reputation } \\
\hline & Pearson Correlation & 1 & & & \\
\hline & Sig. (2-tailed) & & & & \\
\hline & $\mathrm{N}$ & 328 & & & \\
\hline \multicolumn{6}{|c|}{ Brand Predictability } \\
\hline & Pearson Correlation & $.305^{* *}$ & 1 & & \\
\hline & Sig. (2-tailed) & .000 & & & \\
\hline & $\mathrm{N}$ & 328 & 328 & & \\
\hline \multicolumn{6}{|c|}{ Brand Competence } \\
\hline & Pearson Correlation & $.413^{* *}$ & $.288^{* *}$ & 1 & \\
\hline & Sig. (2-tailed) & .000 & .000 & & \\
\hline & $\mathrm{N}$ & 328 & 328 & 328 & \\
\hline \multicolumn{6}{|c|}{ Consumer's Trust in Brand } \\
\hline & Pearson Correlation & $.238^{* *}$ & $.287^{* *}$ & $.524^{* *}$ & 1 \\
\hline & Sig. (2-tailed) & .000 & .000 & .000 & \\
\hline & $\mathrm{N}$ & 328 & 328 & 328 & 328 \\
\hline
\end{tabular}

$* *$. Correlation is significant at the 0.01 level (2-tailed).

Table 3. Beta Coefficients, Standard Error in parenthesis, t-Values in Brackets, and P-Values in italics

\begin{tabular}{ccccc}
\hline Dependent Variable & Constant & Brand Reputation & R Squares & F-Statistic \\
\hline & 2.365 & 0.296 & 0.57 & 19.549 \\
Consumer's Trust in Brand & $(0.230)$ & $(0.67)$ & & \\
& {$[10.267]$} & {$[4.421]$} & & 0.000 \\
\hline
\end{tabular}


Table 4. Beta Coefficients, Standard Error in parenthesis, t-Values in Brackets, and P-Values in italics

\begin{tabular}{rcccc}
\hline Dependent Variable & Constant & $\begin{array}{c}\text { Brand } \\
\text { Competence }\end{array}$ & R Squares & F-Statistic \\
\hline Consumer's Trust in Brand & 1.227 & .600 & 0.275 & 123.549 \\
& $(0.196)$ & $(0.054)$ & & \\
& {$[6.273]$} & {$[11.115]$} & & 0.000 \\
\hline
\end{tabular}

Table 5. Beta Coefficients, Standard Error in parenthesis, t-Values in Brackets, and P-Values in italics

\begin{tabular}{ccccc}
\hline Dependent Variable & Constant & Brand Predictability & R Squares & F-Statistic \\
\hline & 2.321 & 0.324 & 0.083 & 29.371 \\
Consumer's Trust in Brand & $(0.197)$ & $(0.060)$ & & \\
& {$[11.774]$} & {$[5.419]$} & & 0.000 \\
\hline
\end{tabular}

